\title{
Yield of Indeterminate, Small-vine Cowpea Cultivars Unaffected by Uniformity of Within-row Spacing
}

Brian A. Kahn

Department of Horticulture and Landscape Architecture, Oklahoma State University, Stillwater, OK 74078-0511

Peter J. Stoffella

Agricultural Research and Education Center, Institute of Food and Agricultural Sciences, University of Florida, 2199 South Rock Road, Fort Pierce, FL 34945-3138

Daniel I. Leskovar

Texas Agricultural Experiment Station, 1619 Garner Field Road, Uvalde, TX 78801-6205

\section{James R. Cooksey}

Department of Horticulture and Landscape Architecture, Oklahoma State University, Stillwater, OK 74078-0511

Additional index words. Vigna unguiculata, precision planting

Abstract. Cowpea [Vigna unguiculata (L.) Walp.] planters can produce variable withinrow seed spacing. We determined whether precision planting of cowpea would produce a yield advantage over more random planting at the same rate. Studies were conducted from May 1992 to Feb. 1993 at three locations: Uvalde, Texas; Bixby, Okla.; and Fort Pierce, Fla. Seeds of the indeterminate, small-vine cowpea cultivars Mississippi Silver and Pinkeye Purplehull BVR were hand-planted at 42 per $3.15 \mathrm{~m}$ of row. Seeds within rows were either spaced uniformly at $7.5 \mathrm{~cm}$ [control, with $\mathrm{SD}=0$ ] or in one of two random sequences ( $\mathrm{SD}=$ 4.8). At harvest, in Oklahoma and Florida, mean within-row spacings were similar, but SD values of random-sequence plots remained greater than those of control plots. Control plots averaged four more plants at harvest than random-sequence plots in Texas. However, seed yield (seed dry weight per hectare) and harvest index were unaffected by uniformity of within-row spacing at all three locations. Thus, precision seeding of indeterminate, small-vine cowpea cultivars seems unlikely to produce a yield advantage over more random planting at the same rate.

Cowpea planters can produce variable within-row seed spacing, with two or three seeds in one spot and long gaps elsewhere in the row. Growers are beginning to consider pneumatic planters for cowpea stand establishment. We do not know if there is a potential yield benefit from the increased uniformity of seed spacing that is possible with pneumatic planters.

A uniform arrangement of plants within the row theoretically is conducive to maximum yields because such an arrangement minimizes interplant competition (Brewster and Salter, 1980; Moore, 1991). Studies with soy-

Received for publication 3 Feb. 1995. Accepted for publication 21 Apr. 1995. Approved for publication by the Director of the Oklahoma Agricultural Expt. Station. This research was supported in part under Oklahoma project H-2026. Florida Agricultural Expt. Station Journal Series no. R-03628. The cost of publishing this paper was defrayed in part by the payment of page charges. Under postal regulations, this paper therefore must be hereby marked advertisement solely to indicate this fact. bean [Glycine max (L.) Merr.] (Moore, 1991), corn (Zeamays L.)(Kralletal., 1977; Vanderlip et al., 1988), and sunflower(Helianthus annuus L.) (Wade, 1990) have shown that grain yield may decrease as the variability of within-row spacing increases. There are several reports on the effects of plant population on cowpea seed yields (Nangju, 1979; Nangju et al., 1975; Stewart, 1969; Stoffella and Fousek, 1989), but, to our knowledge, effects of uniformity of within-row spacing at a given cowpea plant population have not been reported.

The precision of within-row spacing has been quantified by calculating the SD of the spacing between adjacent plants (Bowman, 1987; Nielsen, 1991; Vanderlip et al., 1988). A negative relationship has been reported between the SD of within-row spacing and grain yield of corn (Nielsen, 1991; Vanderlip et al., 1988), but this relationship has not been investigated in cowpea.

Our objective was to determine whether precision planting of cowpea would produce a yield advantage over more random planting at the same rate.

\section{Materials and Methods}

Seeds of the indeterminate, small-vine cowpea cultivars Mississippi Silver and Pinkeye Purplehull BVR were hand-planted in Uvalde, Texas; Bixby, Okla.; and Fort Pierce, Fla., in plots $\approx 4 \mathrm{~m}$ long. Double-row data plots with appropriate guard rows were used at each location. Data areas in each row were $3.15 \mathrm{~m}$ long. Guard plants at the ends of each row were spaced $7.5 \mathrm{~cm}$ apart within the row.

Data areas in control plots contained 42 seeds spaced uniformly at $7.5 \mathrm{~cm}$ apart within the row $(\mathrm{SD}=0)$. Two random spacing sequences ( $\mathrm{R} 1$ and $\mathrm{R} 2$ ) were generated by creating six units of seven seeds each. Within each unit, each seed was either $0,3,6,9,12$, or 15 $\mathrm{cm}$ from the previous seed. At the zero spacing, two seeds were planted together (perpendicular to the row) at $7.5 \mathrm{~cm}$ from the previous seed. The spacing sequence was randomized within each unit by using a random number table. The completed R1 and R2 sequences had $\mathrm{SD}=4.8$ but differed in their seed distribution patterns within the row and in the "gaps" where adjacent units joined (Fig. 1). The control, R1, and R2 sequences were reproduced on long pipes to ensure accuracy of planting. This system kept the same number of seeds within the data areas of all three spacing sequences, and permitted sequences to be reproduced between locations.

The $2 \times 3$ factorial treatment design was arranged in a $6 \times 6$ Latin square at each location. The first factor was cultivar, and the second factor was spacing sequence.

\section{RANDOM SEQUENCE 1 (R1)}

$[0,3,6,9,12,15][9,3,12,15,6,0][15,0,9,12,3,6][15,3,9,0,6,12][15,3,0,6,12,9][9,12,3,6,15,0]$

RANDOM SEQUENCE 2 (R2)

$[0,3,9,6,12,15][3,12,0,6,15,9][0,9,15,3,6,12][15,3,9,6,12,0][6,0,12,15,9,3][3,12,6,0,15,9]$

Fig. 1. Random within-row spacing sequences used in Texas, Oklahoma, and Florida for a cowpea uniformity experiment from 1992 to 1993 . Each sequence contained six units (shown in brackets) of seven seeds each. Within each unit, each seed was either $0,3,6,9,12$, or $15 \mathrm{~cm}$ from the previous seed. At the zero spacing, two seeds were planted together (perpendicular to the row) at $7.5 \mathrm{~cm}$ from the previous seed. 


\section{Cultural practices}

Uvalde. The experiment was conducted at the Texas Agricultural Expt. Station during Spring and Summer 1992. The soil was a Uvalde silty clay loam (fine-silty, mixed, hyperthermic Aridic Calciustoll). Raised beds $20 \mathrm{~cm}$ high and $20 \mathrm{~cm}$ wide were spaced on 1m centers. Preplant fertilizer $(30 \mathrm{~kg} \mathrm{~N} / \mathrm{ha}$ ) was broadcast and incorporated into the center of each bed. Seeds were planted on 11 May 1992 with one row per bed. Weeds were manually controlled. Insects were chemically controlled as required during crop growth. Iron deficiency was evident, so foliar applications of $5 \% \mathrm{Fe}(200 \mathrm{~g} \mathrm{Fe} / \mathrm{ha})$ were made on 4 and 18 June and on 2 July. Water was applied by furrow irrigation beginning on 26 May and continuing as needed to prevent drought stress.

Bixby. The experiment was conducted at the Vegetable Research Station during Spring and Summer 1992. A Severn very fine sandy loam [coarse-silty, mixed (calcareous), thermic Typic Udifluvent] was prepared with a broadcast preplant-incorporated application of $30 \mathrm{~kg} \mathrm{~N} /$ ha plus 2,6-dinitro- $N, N$-dipropyl-4(trifluoromethyl)benzenamine (trifluralin; 560 $\left.\mathrm{g} \cdot \mathrm{ha}^{-1}\right)$ for weed control. Plots were laid out on the flat (nobeds were used). Seeds were planted on 18 June 1992 with $1 \mathrm{~m}$ between rows in each plot. Insects were chemically controlled as required during crop growth. Water was applied as needed by sprinkler irrigation to prevent drought stress.

Fort Pierce. The experiment was conducted at the Agricultural Research and Education Center during Fall 1992. Dolomitic limestone $\left(1120 \mathrm{~kg} \cdot \mathrm{ha}^{-1}\right)$ was incorporated into an Oldsmar fine sand (sandy, siliceous, hyperthermic Alfic Arenic Haplaquod) before planting. Raised beds $\approx 1.2 \mathrm{~m}$ wide were spaced on 2.1-m centers, as in previous cowpea studies at this location (Kahn and Stoffella, 1985). Preplant fertilization consisted of $114 \mathrm{~N}-75 \mathrm{P}$ $238 \mathrm{~K}\left(\mathrm{~kg} \cdot \mathrm{ha}^{-1}\right)$ as a band application in the center of each bed. The fertilizer rates reflected the leaching potential at Fort Pierce due to sandy soils and high seasonal rainfall. Two rows were planted $1 \mathrm{~m}$ apart on each bed on 14 Sept. 1992. A topdress application of $56 \mathrm{~N}-25 \mathrm{P}-47 \mathrm{~K}\left(\mathrm{~kg} \cdot \mathrm{ha}^{-1}\right)$ was made on 2 Oct. Weeds were manually controlled within the beds and with 1,1'-dimethyl-4,4'-bipyridinium salts (paraquat; $280 \mathrm{~g} \cdot \mathrm{ha}^{-1}$ ) between the beds. Insects and foliar fungi were controlled chemically as required during crop growth. Subsurface irrigation was used throughout the experiment to maintain the water table at $\approx 38 \mathrm{~cm}$ below the soil surface.

\section{Data collection and analysis}

Cultivars were harvested individually as soon as most of the pods were dry. Each of the two data rows was harvested separately and treated as one of two samples from a given plot. The appropriate marked pipe (used earlier to assist in planting) was placed next to each row to be harvested. Plants in the $3.15-\mathrm{m}$ data areas were counted and cut off at soil level. At the same time, the locations of miss- ing plants were recorded with the aid of the marked pipe. (This second step was inadvertently omitted in Uvalde; thus, SD values could not be calculated there.) Small, barren plants (those lacking at least one pod containing at least one developed seed) were counted as missing because they provided little competition and added nothing to seed yield. Unabscised leaves were removed, and all remaining plant material was dried at 55 to $65 \mathrm{C}$ for $\geq 4$ days before weighing. A random sample of 100 undamaged seeds was weighed to determine average weight per individual seed. Other variables were determined as follows: deleafed forage yield (dry weight of stems, podwalls, and seeds per area), seed yield (seed dry weight per area), and harvest index (seed yield/deleafed forage yield).

Data were evaluated by location using analysis of variance procedures. Main effects of cultivars, spacing sequences, and cultivar $x$ spacing sequence interactions were tested. Orthogonal contrasts were used to partition main effects of spacing sequences. Values for the coefficient of variation (Cv) were reported as measures of experimental variability.

Table 1. Response of 'Mississippi Silver' cowpea to uniformity of within-row spacing in Uvalde, Texas.

\begin{tabular}{|c|c|c|c|c|c|c|}
\hline Spacing sequence & $\begin{array}{l}\text { Plants/ } \\
3.15 \mathrm{~m} \text { of row } \\
\text { (no.) }\end{array}$ & $\begin{array}{c}\text { Mean } \\
\text { within-row } \\
\text { spacing } \\
(\mathrm{cm})\end{array}$ & $\begin{array}{l}\text { Deleafed } \\
\text { forage } \\
\text { yield } \\
\left(\mathrm{Mg} \cdot \mathrm{ha}^{-1}\right)\end{array}$ & 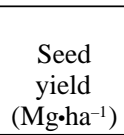 & $\begin{array}{l}\text { Harvest } \\
\text { index }^{x}\end{array}$ & $\begin{array}{r}\text { Seed wt } \\
\text { (mg/seed) }\end{array}$ \\
\hline Random 1 (R1) & 34 & 9.3 & 3.4 & 1.7 & 0.50 & 196 \\
\hline Random 2 (R2) & 35 & 9.0 & 3.8 & 1.8 & 0.48 & 207 \\
\hline Control & 39 & 8.2 & 3.7 & 1.8 & 0.48 & 197 \\
\hline \multicolumn{7}{|l|}{ 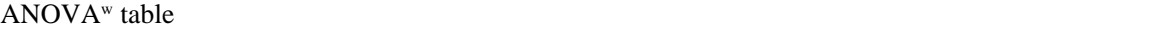 } \\
\hline Spacing sequence & $* *$ & $* *$ & NS & NS & NS & $* *$ \\
\hline $\mathrm{CV}$ & 7 & 7 & 9 & 11 & 4 & 3 \\
\hline \multicolumn{7}{|l|}{ Contrasts } \\
\hline Control vs. (R1 + R2) & ** & ** & NS & NS & NS & NS \\
\hline R1 vs. R2 & NS & NS & NS & NS & NS & $* *$ \\
\hline
\end{tabular}

${ }^{2}$ At planting, there were 42 seeds in each 3.15 -m plot.

${ }^{y}$ Calculated as dry weight of (stems + podwalls + seeds).

${ }^{\mathrm{x}}$ Calculated as (seed yield/deleafed forage yield).

${ }^{\mathrm{w}} \mathrm{ANOVA}=$ analysis of variance.

Ns, ${ }^{* *}$ Nonsignificant at $P>0.05$ or significant at $P \leq 0.01$, respectively.

Table 2. Response of 'Mississippi Silver' (MS) and 'Pinkeye Purplehull BVR' (PP) cowpeas to uniformity of within-row spacing in Bixby, Okla.

\begin{tabular}{|c|c|c|c|c|c|c|c|}
\hline \multirow[b]{2}{*}{ Treatments } & \multirow{2}{*}{$\begin{array}{c}\text { Plants/ } \\
3.15 \text { m of row } \\
\text { (no.) }\end{array}$} & \multicolumn{2}{|c|}{$\begin{array}{l}\text { Within-row } \\
\text { spacing }\end{array}$} & \multirow{2}{*}{ 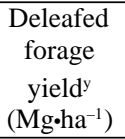 } & \multirow{2}{*}{$\begin{array}{c}\text { Seed } \\
\text { yield } \\
\left({\left.\mathrm{Mg} \cdot h \mathrm{~h}^{-1}\right)}\right.\end{array}$} & \multirow[b]{2}{*}{$\begin{array}{c}\text { Harvest } \\
\text { index }^{\mathrm{x}}\end{array}$} & \multirow[b]{2}{*}{$\begin{array}{c}\text { Seed wt } \\
(\mathrm{mg} / \mathrm{seed})\end{array}$} \\
\hline & & $\begin{array}{l}\text { Mean } \\
(\mathrm{cm})\end{array}$ & $\begin{array}{c}\mathrm{SD} \\
(\mathrm{cm})\end{array}$ & & & & \\
\hline \multicolumn{8}{|l|}{$\overline{\text { Cultivar (C) }}$} \\
\hline MS & 30 & 10.8 & 7.2 & 5.8 & 2.6 & 0.45 & 240 \\
\hline PP & 30 & 10.9 & 7.6 & 4.9 & 1.8 & 0.37 & 195 \\
\hline \multicolumn{8}{|l|}{ Spacing sequence $(\mathrm{S})$} \\
\hline Random 1 (R1) & 30 & 10.6 & 8.0 & 5.4 & 2.3 & 0.43 & 217 \\
\hline Random 2 (R2) & 29 & 11.0 & 8.2 & 5.3 & 2.2 & 0.41 & 218 \\
\hline Control & 30 & 10.8 & 5.8 & 5.4 & 2.2 & 0.40 & 219 \\
\hline \multicolumn{8}{|l|}{ ANOVA $^{\mathrm{w}}$ table } \\
\hline $\mathrm{C}$ & NS & NS & NS & $* *$ & $* *$ & $* *$ & $* *$ \\
\hline $\mathrm{S}$ & NS & NS & $* *$ & NS & NS & NS & NS \\
\hline $\mathrm{C} \times \mathrm{S}$ & NS & NS & NS & NS & NS & NS & NS \\
\hline $\mathrm{CV}$ & 12 & 13 & 26 & 10 & 11 & 5 & 2 \\
\hline \multicolumn{8}{|l|}{ Contrasts } \\
\hline Control vs. (R1 + R2) & NS & NS & $* *$ & NS & NS & NS & NS \\
\hline R1 vs. R2 & NS & NS & NS & NS & NS & NS & NS \\
\hline
\end{tabular}

${ }^{\mathrm{z}}$ At planting, there were 42 seeds in each $3.15-\mathrm{m}$ plot.

${ }^{y}$ Calculated as dry weight of (stems + podwalls + seeds).

${ }^{\mathrm{x}}$ Calculated as (seed yield/deleafed forage yield).

${ }^{\mathrm{w}} \mathrm{ANOVA}=$ analysis of variance.

Ns, ** Nonsignificant at $P>0.05$ or significant at $P \leq 0.01$, respectively.

\section{Results and Discussion}

'Pinkeye Purplehull BVR' plants exhibited severe chlorosis in Texas and never reached maturity. Thus, Texas data were limited to well to the Fe sprays.

We had hypothesized that the extremely crowded within-row spacings in the random sequences would result in some plant loss due inse competition. However, Texas was (Table 1), perhaps because most of the seeds that were sown produced plants. Despite diferences averaging four to five plants per plot, pacing sequences had no effect on cowseed weight was higher with R2 than with R1, which seemed anomalous because R2 and R1 did not differ significantly in within-row spacTable 1) plots at harvest (Table 2). 'Mississippi Silver'

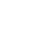


plants were higher in deleafed forage yield, seed yield, harvest index, and individual seed weight than 'Pinkeye Purplehull BVR' plants (Table 2). Spacing sequence had no effect on cowpea yield, harvest index, or seed weight in Oklahoma. There also were no significant $(P \leq$ $0.05)$ cultivar $\times$ spacing sequence interactions (Table 2).

Stands differed among cultivars but not among spacing sequences in Florida (Table 3 ). The SD values of within-row spacing for control plots remained lower than those of random sequence plots at harvest (Table 3), as in Oklahoma. 'Mississippi Silver' plants were higher in deleafed forage yield, seed yield, and harvest index than 'Pinkeye Purplehull BVR' plants (Table 3), again as in Oklahoma. Spacing sequence had no effect on cowpea yield or harvest index in Florida. However, a cultivar $\times$ spacing sequence interaction was evident for individual seed weight (Table 3). Analysis with an interaction least significant difference (not presented) showed that uniformity of within-row spacing did not affect individual seed weight of 'Mississippi Silver'. However, 'Pinkeye Purplehull BVR' plants in the two random sequences produced higher individual seed weights than plants of this cultivar in the control.

Precision planting has produced yields similar to irregular planting at the same seeding rates in other crops, including onion (Allium cepa L.) (Brewster and Salter, 1980) and pea (Pisum sativum L.) (Heath and Hebblethwaite, 1987). Even in soybean (Moore, 1991), corn (Vanderlip et al., 1988), and sunflower (Wade, 1990), where grain yield has decreased as variability of within-row spacing has increased, results have not been consistent. Wilcox (1974) concluded that accurate planting to precise populations was not essential to produce maximum soybean yields for specific cultivars. Bowman (1987) recommended planting corn to a stand, noting that yield was not reduced in unthinned rows with less uniform stands compared to more uniform, thinned rows, with percentages of desired stands similar to those of unthinned rows. Robinson et al. (1982) reported that within-row spacing uniformity significantly $(P \leq 0.05)$ affected sunflower seed yield in only four of nine trials. Plant architectural differences partially may explain why some species are more likely to respond to precision planting than others. Corn and sunflower are tall plants compared to grain legumes such as cowpea and soybean, which are short and more bushy. Greater lodging was the most consistent detriment of nonuniform plant spacing in sunflower (Robinson et al., 1982).

Determinate cowpea cultivars might have responded differently. However, compensation for irregular or gap-filled stands was not influenced by a determinate vs. an indeterminate growth habit among soybean cultivars (Pepper and Walker, 1988). Also, more extreme variations in spacing uniformity might have affected yield. Brewster and Salter (1980) suggested that the potential advantages of regular within-row spacing may be greatest when there are several cases of two or more seeds being sown together. Hicks et al. (1990) found

Table 3. Response of 'Mississippi Silver' (MS) and 'Pinkeye Purplehull BVR' (PP) cowpeas to uniformity of within-row spacing in Fort Pierce, Fla.

\begin{tabular}{|c|c|c|c|c|c|c|c|}
\hline \multirow[b]{2}{*}{ Treatments } & \multirow{2}{*}{$\begin{array}{c}\text { Plants/ } \\
3.15 \mathrm{~m}^{\text {of } \text { row }^{2}} \\
\text { (no.) }\end{array}$} & \multicolumn{2}{|c|}{$\begin{array}{l}\text { Within-row } \\
\text { spacing }\end{array}$} & \multirow{2}{*}{ 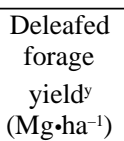 } & \multirow{2}{*}{$\begin{array}{c}\text { Seed } \\
\text { yield } \\
\left(\mathrm{Mg} \cdot h \mathrm{a}^{-1}\right)\end{array}$} & \multirow[b]{2}{*}{$\begin{array}{c}\text { Harvest } \\
\text { index }^{x}\end{array}$} & \multirow[b]{2}{*}{$\begin{array}{l}\text { Seed wt } \\
\text { (mg/seed) }\end{array}$} \\
\hline & & $\begin{array}{l}\text { Mean } \\
(\mathrm{cm})\end{array}$ & $\begin{array}{c}\mathrm{SD} \\
(\mathrm{cm})\end{array}$ & & & & \\
\hline \multicolumn{8}{|l|}{ Cultivar (C) } \\
\hline MS & 33 & 9.6 & 5.8 & 3.1 & 1.6 & 0.49 & 168 \\
\hline PP & 31 & 10.4 & 6.6 & 2.8 & 1.3 & 0.44 & 150 \\
\hline \multicolumn{8}{|l|}{ Spacing sequence (S) } \\
\hline Random 1 (R1) & 32 & 10.1 & 6.9 & 3.0 & 1.4 & 0.46 & 159 \\
\hline Random 2 (R2) & 32 & 10.0 & 7.2 & 3.0 & 1.4 & 0.47 & 161 \\
\hline Control & 32 & 10.0 & 4.6 & 3.0 & 1.4 & 0.47 & 157 \\
\hline \multicolumn{8}{|l|}{ ANOVA $^{w}$ table } \\
\hline C & $*$ & $*$ & * & * & $* *$ & $* *$ & $* *$ \\
\hline $\mathrm{S}$ & NS & NS & $* *$ & NS & NS & NS & $*$ \\
\hline $\mathrm{C} \times \mathrm{S}$ & NS & NS & NS & NS & NS & NS & $*$ \\
\hline $\mathrm{CV}$ & 12 & 14 & 28 & 19 & 23 & 8 & 3 \\
\hline \multicolumn{8}{|l|}{ Contrasts } \\
\hline Control vs. $(\mathrm{R} 1+\mathrm{R} 2)$ & NS & NS & $* *$ & NS & NS & NS & $*$ \\
\hline R1 vs. R2 & NS & NS & NS & NS & NS & NS & NS \\
\hline
\end{tabular}

${ }^{\mathrm{z}}$ At planting, there were 42 seeds in each $3.15-\mathrm{m}$ plot.

${ }^{y}$ Calculated as dry weight of (stems + podwalls + seeds).

${ }^{x}$ Calculated as (seed yield/deleafed forage yield).

${ }^{\mathrm{w}} \mathrm{ANOVA}=$ analysis of variance.

Ns,,$* * *$ Nonsignificant at $P>0.05$ or significant at $P \leq 0.05$ or 0.01 , respectively.

significant reductions in soybean yields at equal populations of $\approx 185,000$ plants/ha when stand gaps were increased from 30 to $60 \mathrm{~cm}$.

We found no negative relationship between the SD of within-row spacing and seed yield (seed dry weight per hectare) for cowpea. Individual seed weight sometimes responded to spacing uniformity, as others have noted in soybean (Costa et al., 1980; Moore, 1991). However, this response may be of little practical consequence because seed dry weight per hectare and harvest index were not affected by spacing uniformity at any of the three locations. The lack of significant effects on harvest index in our studies indicates yield compensation by plants at irregular withinrow spacings. Stoffella and Fleming (1992) reported yield compensation responses by cowpeas grown with various stand deficiencies. Soybean also has demonstrated high levels of yield compensation for missing plants (Pepper and Walker, 1988; Shibles and Weber, 1966). We conclude that precision seeding of indeterminate, small-vine cowpea cultivars seems unlikely to produce a yield advantage over more random planting at the same rate.

\section{Literature Cited}

Bowman, D.T. 1987. Feasibility studies on planting corn trials to a stand. Crop Sci. 27:1231-1234.

Brewster, J.L. and P.J. Salter. 1980. A comparison of the effects of regular versus random within-row spacing on the yield and uniformity of size of spring-sown bulb onions. J. Hort. Sci. 55:235238.

Costa, J.A., E.S. Oplinger, and J.W. Pendleton. 1980. Response of soybean cultivars to planting patterns. Agron. J. 72:153-156.

Heath, M.C. and P.D. Hebblethwaite. 1987. Precision drilling combining peas (Pisum sativum $\mathrm{L}$.) of contrasting leaf types at varying densities. J. Agr. Sci. (Cambridge) 108:425-430.

Hicks, D.R., W.E. Lueschen, and J.H. Ford. 1990. Effects of stand density and thinning on soybean. J. Prod. Agr. 3:587-590.

Kahn, B.A. and P.J. Stoffella. 1985. Yield compo- nents of cowpeas grown in two environments. Crop Sci. 25:179-182.

Krall, J.M., H.A. Esechie, R.J. Raney, S. Clark, G. TenEyck, M. Lundquist, N.E. Humburg, L.S. Axthelm, A.D. Dayton, and R.L. Vanderlip. 1977. Influence of within-row variability in plant spacing on corn grain yield. Agron. J. 69:797-799.

Moore, S.H. 1991. Uniformity of plant spacing effect on soybean population parameters. Crop Sci. 31:1049-1051.

Nangju, D. 1979. Effect of density, plant type, and season on growth and yield of cowpea. J. Amer. Soc. Hort. Sci. 104:466-470.

Nangju, D., T.M. Little, and A. Anjorin-Ohu. 1975. Effect of plant density and spatial arrangement on seed yield of cowpea [Vigna unguiculata (L.) Walp.]. J. Amer. Soc. Hort. Sci. 100:467-470.

Nielsen, B. 1991. Stand establishment uniformity in corn. Mimeo AGRY-91-1, Agronomy Dept., Purdue Univ., West Lafayette, Ind.

Pepper, G.E. and J.T. Walker. 1988. Yield compensation for stand deficiencies by determinate and indeterminate growth-habit soybean. Agron. J. $80: 1-4$.

Robinson, R.G., J.H. Ford, W.E. Lueschen, D.L. Rabas, D.D. Warnes, and J.V. Wiersma. 1982. Response of sunflower to uniformity of plant spacing. Agron. J. 74:363-365.

Shibles, R.M. and C.R. Weber. 1966. Interception of solar radiation and dry matter production by various soybean planting patterns. Crop Sci. 6:55-59.

Stewart, F.B. 1969. The effect of spacing and fertilization on yield of southern peas. J. Amer. Soc. Hort. Sci. 94:337-338.

Stoffella, P.J. and M.F. Fleming. 1992. Yield responses to stand deficiency patterns of cowpeas grown at a narrow in-row spacing. Proc. Interamerican Soc. Trop. Hort. 36:88-92.

Stoffella, P.J. and D.J. Fousek. 1989. Influence of within-row spacings on distribution patterns of yield components in cowpeas. Scientia Hort. 41:18.

Vanderlip, R.L., J.C. Okonkwo, and J.A. Schaffer. 1988. Corn response to precision of within-row plant spacing. Applied Agr. Res. 3:116-119.

Wade, L.J. 1990. Estimating loss in grain yield due to suboptimal plant density and non-uniformity in plant spacing. Austral. J. Expt. Agr. 30:251-255.

Wilcox, J.R. 1974. Response of three soybean strains to equidistant spacings. Agron. J. 66:409-412. 